\title{
Familial craniosynostosis, anal anomalies, and porokeratosis: CAP syndrome
}

\author{
N Flanagan, S A Boyadjiev, J Harper, L Kyne, M Earley, R Watson, E W Jabs, \\ M T Geraghty
}

\begin{abstract}
We report on the occurrence of coronal craniosynostosis, anal anomalies, and porokeratosis in two male sibs. A third male sib was phenotypically normal as were the parents. The occurrence of these three clinical features has, to our knowledge, not been reported before. Cutaneous or anal anomalies or both have been reported in a number of syndromes associated with craniosynostosis, including Crouzon, Pfeiffer, Apert, and Beare-Stevenson syndromes. These syndromes are associated with mutations in the fibroblast growth factor receptor genes FGFR1, FGFR2, and FGFR3. They are inherited in an autosomal dominant fashion. In contrast, the cases we report do not carry any of the common FGFR mutations and the pedigree suggests autosomal or $X$ linked recessive inheritance.

$(\Im$ Med Genet 1998;35:763-766)
\end{abstract}

Keywords: craniosynostosis; anal anomalies; porokeratosis; fibroblast growth factor receptor

Department of
Dermatology, St James
Hospital, Dublin,
Ireland
N Flanagan
L Kyne
R Watson

Center for Medical Genetics, Blalock 1004, Johns Hopkins University School of Medicine, $600 \mathrm{~N}$ Wolfe Street, Baltimore, MD 21287-4922, USA $S$ A Boyadjiev EW Jabs

M T Geraghty

The Hospital for Sick Children, Great Ormond Street, London, UK $\mathrm{J}$ Harper

\section{The Children's} Hospital, Temple Street, Dublin, Ireland M Earley

Correspondence to: Dr Geraghty.

Received 5 August 1997 Revised version accepted for publication 2 February 1998
Porokeratosis is a chronic progressive disease characterised clinically by the formation of annular, flat lesions with raised scaly borders. Several clinical types have been described including disseminated superficial actinic, palmoplantar, and Mibelli types. ${ }^{1}$ Little is known of the genetics of porokeratosis. It may occur sporadically or be inherited in an autosomal dominant fashion. Instability of chromosome 3 has been reported and may be a factor in the tendency to develop squamous cell carcinoma of the skin. ${ }^{2}$ Apart from an association with Down syndrome, we are unaware of any other reports of porokeratosis in association with other congenital anomalies. ${ }^{3}$ Craniosynostosis has not been reported in porokeratosis. However, cutaneous and anal anomalies have been described in other syndromes associated with craniosynostosis, for example, Apert, Crouzon, Pfeiffer, and Beare-Stevenson syndromes respectively. ${ }^{4-8}$ We present two male sibs suffering from craniosynostosis, anal anomalies, and diffuse porokeratosis. These patients are the first reported cases of this clinical triad. The affected boys have one normal sib and both parents are phenotypically normal. This suggests that the disorder is inherited in an autosomal or $\mathrm{X}$ linked recessive fashion, but non-penetrance and gonadal mosaicism cannot be excluded.

\section{Case reports}

CASE 1

A male infant was born at term by normal vaginal delivery following a normal pregnancy. $\mathrm{He}$ was the third child of healthy, unrelated parents. The oldest boy in the family (described below) had a history of craniosynostosis, anal anomalies, and porokeratosis. The second male sib was phenotypically normal. Clinical examination of both parents was normal. An extended family history did not indicate any other abnormalities, in particular there was no history of craniosynostosis, limb, anal, or skin anomalies. The infant's birth weight was $3500 \mathrm{~g}$ and he had good Apgar scores. At birth he was noted to have microcephaly (head circumference $22 \mathrm{~cm}$ ), brachycephaly, and a high forehead. The anterior fontanelle was widely patent with normal sagittal sutures. The coronal sutures were fused and the posterior fontanelle was absent. He had a bifid scrotum and an anterior, ectopic, low, imperforate anus (fig 1). The latter required treatment by anoplasty followed by regular dilatations. The skin was normal at birth.

At 3 months of age he developed erythematous, scaly plaques on the cheeks, ears, fingers, toes, and posterior scalp. Examination showed two $4 \mathrm{~cm}$ scaly, crusted plaques on both cheeks with some central clearing (fig 2). There was scaling of the posterior scalp, crusting of the helix of his ear, and erythema of the nail fold of the left thumb and index fingers without any associated nail dystrophy. Skin biopsy showed a mild, perivascular, chronic inflammatory cell infiltrate in the upper dermis, a number of necrotic keratinocytes in the epidermis, and vacuolation of the basal cell layer, but no cornoid lamella. He had a number of normal investigations including full blood count, electrolytes and biochemistry, immunoglobulin levels, complement assays, and neutrophil and lymphocyte function tests. Chromosome analysis was normal. Total genomic DNA was

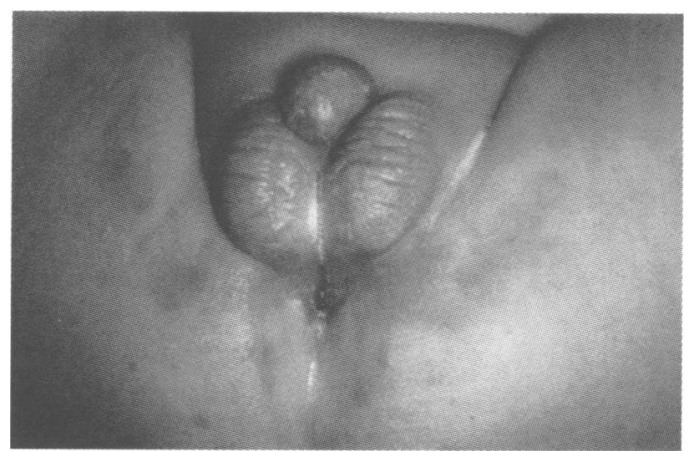

Figure 1 Case 1, aged 3 months, showing the anterio position of the anus and bifid scrotum. 


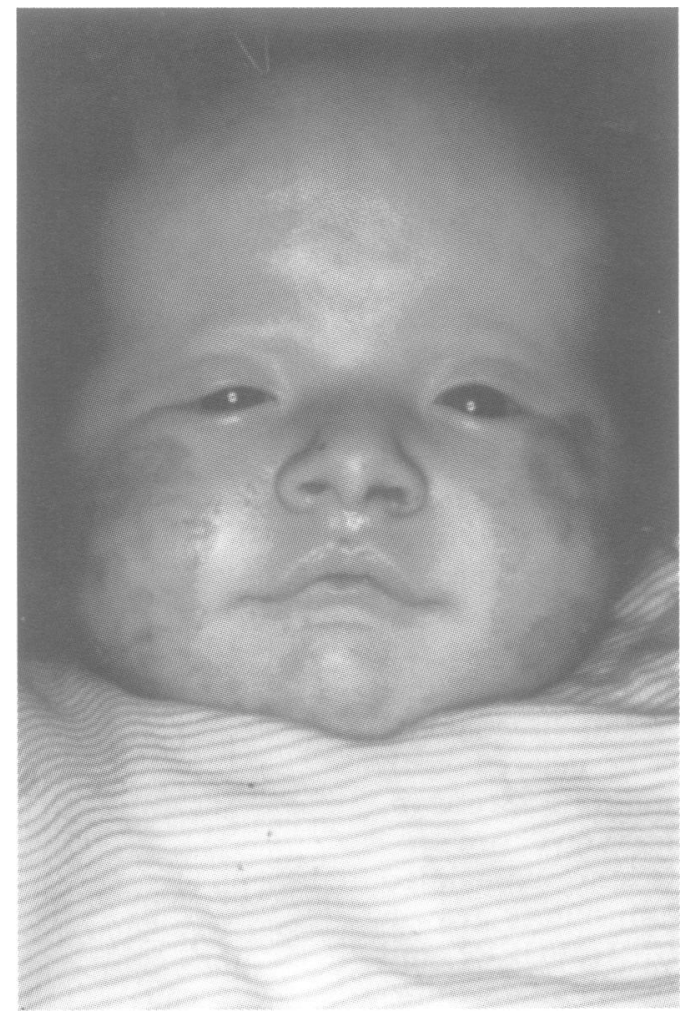

Figure 2 Case 1, aged 3 months, showing scaly, crusted, erythematous plaques on both cheeks with some central clearing. (Photographs reproduced with permission.)

extracted from the patient's blood. Exon IIIa of the FGFR1 gene, ${ }^{9}$ exons IIIa, IIIc, and 10 of the FGFR2 gene, ${ }^{56}$ exons IIIa and 10 of the FGFR3 gene, ${ }^{810}$ and exon 1 of the TWIST gene were amplified by PCR. ${ }^{11} 12$ The amplified product was surveyed by direct sequencing for the presence of mutations as previously published. None was found. Mutations in these exons are the only ones reported to date as causing Crouzon, Pfeiffer, Jackson-Weiss, Beare-Stevenson, Apert, and Saethre-Chotzen syndromes respectively. ${ }^{518}$ No mutation was found in FGFR2 exon IIIb, which is alternatively spliced in, to code for the KGFR isoform that is expressed in epithelial cells.

CASE 2

The oldest brother of case 1 , now aged 8 , was similarily found at birth to have craniosynostosis with fusion of his coronal and sagittal sutures. Other anomalies noted were anterior position of the anus, hypospadias, and incurving of his fourth toes bilaterally. His presentation and early course have been described previously. ${ }^{19}$ At 4 weeks of age he developed a scaly facial eruption and lesions similiar to paronychia on his fingers and toenails. His rash slowly extended with the development of lesions on the arms, legs, and perineum. By 6 months of age he had a symmetrical eruption affecting the face (fig 3), limbs, and perineum, but sparing the trunk. The facial rash was reticulate, scaly, and erythematous with areas of poikiloderma over the cheeks and chin. There was focal crusting on the scalp and the margins of the pinnae. The acral rash was strikingly symmetrical with figurate and annular patterns. Individual lesions were well

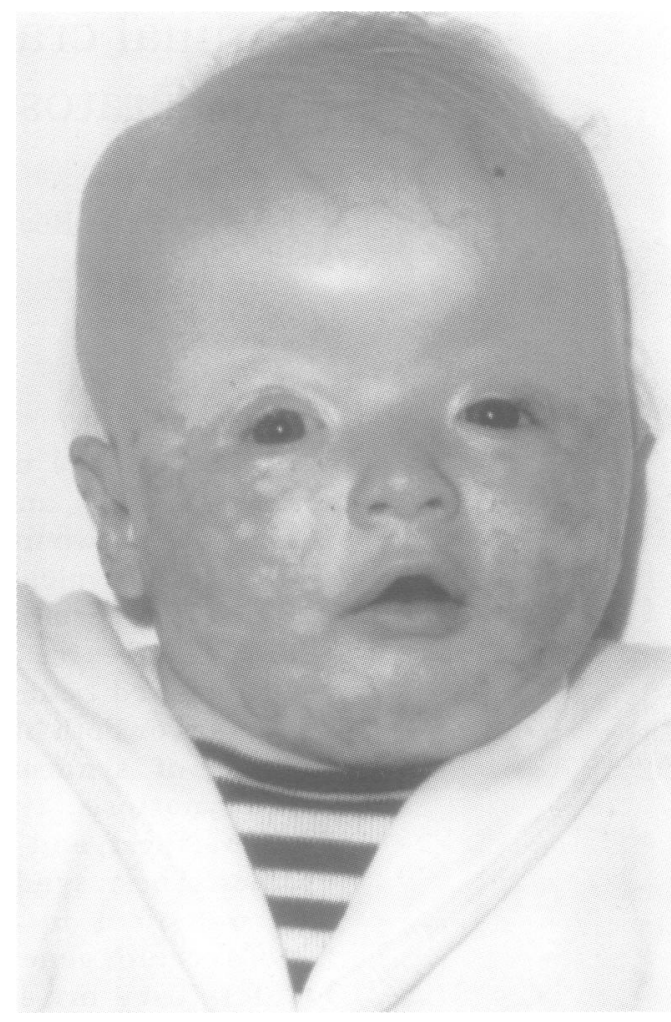

Figure 3 Case 2, aged 6 months. A symmetrical, reticulate, erythematous eruption is seen on both cheeks, similiar to case 1 (reprinted with permission of the British fournal of Dermatology).

demarcated, erythematous, hyperkeratotic plaques with raised, brown, hyperpigmented margins. He had hypotrichosis of the scalp and eyebrows, delayed primary dentition, and normal nails. Skin biopsies were performed at 7, 9, and 13 months. The first two biopsies were non-diagnostic. The third biopsy, through the edge of a lesion, showed epidermal changes with parakeratosis, acanthosis with several dyskeratotic cells, and an increase in the number of mitotic figures. It also showed a cornoid lamella and focal vacuolar degeneration of the basal layer, characteristic of porokeratosis (fig 4). Normal investigations included full blood count, immunoglobulins, $T$ cell subsets, and zinc levels. Magnesium levels were reduced on one occasion but were normal on subsequent testing. Chromosome analysis and DNA repair studies on cultured fibroblasts were normal.

Before confirmation of the diagnosis, the oldest sib was treated with zinc supplements, biotin, topical steroids, antifungal agents, antibacterial agents, and emollients. None of these agents resulted in any benefit. Following confirmation of the diagnosis of porokeratosis at the age of 13 months, he was treated with a trial of etretinate at a dose of $1 \mathrm{mg} / \mathrm{kg} /$ day for two months. There was no response. At the age of 14 months, koebnerisation was seen at the margins of his nappy area and at the scar site after surgical correction of his craniosynostosis. Wound healing was normal after further surgical correction of his craniosynostosis in 1994 and after correction of hypospadias in 1995. Over time, the lesions on his limbs and nappy area have become much paler but the characteristic raised border of porokeratosis has become more prominent (fig 5). Poikiloderma 


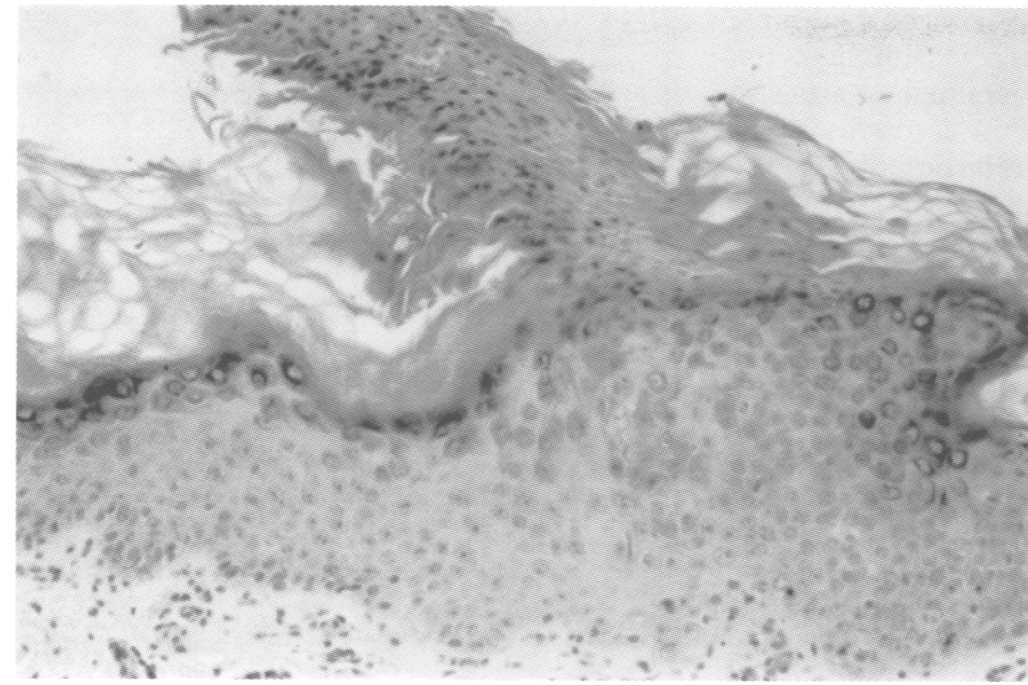

Figure 4 Case 2, $H$ E E, low power. This shows a cornoid lamella consistent with a diagnosis of porokeratosis (reprinted with permission of the British fournal of Dermatology).

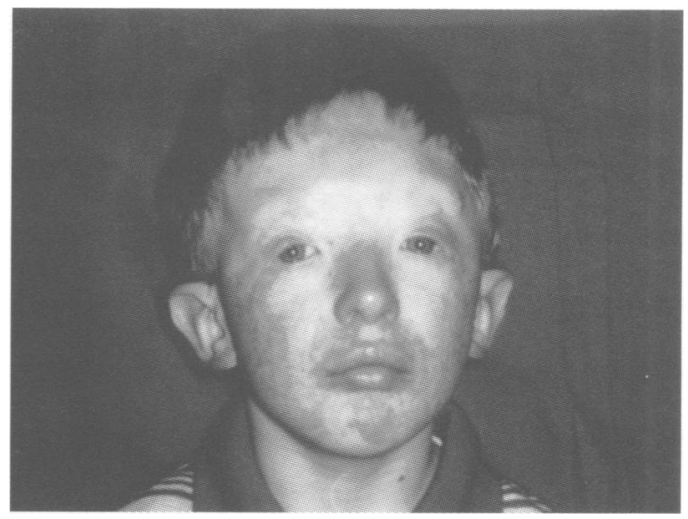

Figure 6 Case 2, aged 8 years, showing a reticulate poikilodermatous eruption on his cheeks and chin.

ogy is seen only at the edge of the lesion where a column of poorly staining parakeratotic stratum corneum cells is seen, the cornoid lamella. It is important to note that, as in our case, several biopsies ideally taken from the edge of a lesion may be needed before the diagnosis is confirmed. It has been suggested that the cornoid lamella marks the border between an expanding clone of mutant keratinocytes and the normal epidermis. ${ }^{20}$ Although the cornoid lamella is characteristic of porokeratosis, it may also be seen in a number of other disorders, such as verruca vulgaris and solar keratosis. ${ }^{21}$ Development of porokeratotic lesions has been found to follow exposure to ultraviolet radiation, infectious disease, mechanical trauma, and following immunosuppressive therapy. Autosomal dominant inheritance has been described in the various types of porokeratosis in several families. ${ }^{22-25}$ Clinically a number of variants of porokeratosis have been described. Those reported in children include linear porokeratosis, punctate porokeratosis, and porokeratosis of Mibelli. Our patients do not fit any classic variant but most closely resemble porokeratosis of Mibelli. An atypical feature is the poikiloderma on the face. However, there were no other features suggestive of Rothmund-Thompson or Bloom syndromes, respectively.

Craniosynososis is the premature fusion of the bones of the skull that disrupts coordinate growth and often results in abnormal skull shape. It is an aetiologically and genetically heterogeneous condition. It may be primary, owing to some unspecified defect in the suture itself or secondary to some underlying problem. Primary craniosynostosis may be associated with other anomalies such as limb anomalies in Saethre-Chotzen, Pfeiffer, and JacksonWeiss syndromes. Craniosynostosis has been reported in association with a number of cutaneous disorders, such as acneiform eruptions in Apert syndrome, acanthosis nigricans in Crouzon syndrome, and cutis gyrata in BeareStevenson syndrome. ${ }^{26-28}$ Mutations in the FGFR genes have been reported in these syndromes. Most patients with Crouzon syndrome have a mutation that is thought to affect the bacterially expressed kinase isoform (BEK) of FGFR2, which is expressed in the developing skeleton. However, a mutation in the FGFR3 gene (A391Glu) has been reported in is characterised clinically by the formation annular plaques with central atrophy and surrounded by a raised keratotic wall and more rarely a furrow. The characteristic histopathol- 
a number of families with Crouzon syndrome and acanthosis nigricans. ${ }^{82}$ Although not widely appreciated, anal anomalies are also known to occur in some of the above disorders. Imperforate anus has been described in a patient with Crouzon syndrome who had a W290G mutation in exon IIIa of the FGFR2 gene. ${ }^{6}$ This mutation affects both isoforms of FGFR2, that is, BEK and keratinocyte growth factor receptor (KGFR). The latter is expressed in skin and the epithelial linings of inner spaces such as the anus. ${ }^{30}{ }^{31}$ Anal anomalies, such as anterior placement, are also findings in the Beare-Stevenson syndrome, which results from mutations in the FGFR2 gene, proximal to the transmembrane domain and thus affecting both isoforms of this gene. ${ }^{5}$ Finally, anal anomalies have been reported in two of 36 patients with Apert syndrome. ${ }^{6}$ All of the above craniosynostosis syndromes are inherited in an autosomal dominant fashion. While we cannot exclude non-penetrance of a dominant gene in our pedigree, the normal examination of the parents and lack of reported anomalies in the extended family do not support this mode of inheritance. Finally, while mutations in the genes for fibroblast growth factor receptors (FGFRs) have been associated with Crouzon, Apert, and Pfeiffer syndromes, we were unable to find any of the mutations currently reported in association with these disorders.

In summary we report a unique family in which two of the three male sibs presented with porokeratosis, anal anomalies, and craniosynostosis. The pedigree suggests the disorder is inherited in an autosomal recessive fashion, but $\mathrm{X}$ linked inheritance or gonadal mosaicism cannot be excluded.

This work was in part supported by the NIH, T32 GM7471 (SAB), RO1 DE11441 (EWJ).

1 Schamroth JM, Zlotogorski A, Gilead L. Porokeratosis of Mibelli. Acta Derm Venereol (Stockh) 1997;77:207-13.

2 Scappaticci S, Lambiase S, Orecchia G, Fraaccaro M. Clonal chromosomal abnormalities with preferential involvement of chromosome 3 in patients with porokeratosis of Mibelli. Cancer Genet Cytogenet 1989;43:89-94.

3 Walther L. Porokeratosis Mibelli bei Mongolismus und Walther L. Porokeratosis Mibelli bei Mongolism
multiplen Missbildungen. Hautarzt 1966;17:363-5.

multiplen Missbildungen. Hautarzt 1966;17:363-5.
Orlow SJ. Cutaneous findings in craniofacial malformation Orlow SJ. Cutaneous findings in craniofacial mat
syndromes. Arch Dermatol 1992;128:1379-86.

5 Pryzlepa KA, Paznekas W, Zhang M, et al. Fibroblast growth factor receptor 2 mutations in Beare-Stevenson cutis gyrata syndrome. Nat Genet 1996;13:492-4.

6 Park WJ, Meyers GA, Li X, et al. Novel FGFR2 mutations in the Crouzon and Jackson-Weiss syndromes show allelic heterogeneity and phenotypic variability. Hum Mol Genet 1995;4:1229-33.
7 Park WJ, Theda C, Maestri NE, et al. Analysis of phenotypic features and FGFR2 mutations in Apert syndrome. Am Hum Genet 1995;57:321-8.

8 Meyers GA, Orlow SJ, Munro IR, Pryzlepa KA, Jabs EW Fibroblast growth factor receptor 3 (FGFR3) transmem brane mutation in Crouzon syndrome with acanthosis nig ricans. Nat Genet 1995;11:462-4.

9 Muenke M, Schell U, Hehr A, et al. A common mutation in the fibroblast growth factor receptor 1 gene in Pfeiffer syndrome. Nat Genet 1994;8:269-74.

10 Bellus GA, Gaudenz K, Kackai EH, et al. Identical mutations in three different fibroblast growth factor genes in autosomal dominant craniosynostosis syndromes. Nat Genet 1996;14:174-6.

11 Howard TD, Paznekas WA, Green ED, et al. Mutations in TWIST, a basic helix-loop-helix transcription factor, in Saethre-Chotzen syndrome. Nat Genet 1997;15:36-41.

12 El Ghouzzi V, Le Merrer M, Perrin-Schmitt F, et al. Mutations of the TWIST gene in the Saethre-Chotzen syndrome. Nat Genet 1997;15:42-6.

13 Reardon W, Winter RM, Rutland P, Pulleyn LJ, Jones BM Malcolm S. Mutations in fibroblast growth factor receptor-2 gene cause Crouzon syndrome. Nat Genet 1994; 8:98-103.

14 Jabs EW, Li X, Scott AF, et al. Jackson-Weiss and Crouzon syndromes are allelic with mutations in fibroblast growt factor receptor 2. Nat Genet 1994;8:275-9.

15 Wilkie AOM, Slaney SF, Oldridge M, et al. Apert syndrome results from localized mutations of FGFR2 and are allelic with Crouzon syndrome. Nat Genet 1995;9:165-72.

16 Lajeunie E, Ma HW, Bonaventure J, Munnich A, Le Merrer M, Reenier D. FGFR2 mutations in Pfeiffer syndrome. Nat Genet 1995;9:108.

17 Rutland P, Pulleyn LJ, Reardon W, et al. Identical mutations in the FGFR2 gene cause both Pfeiffer and Crouzon syndrome phenotypes. Nat Genet 1995;9:173-6.

18 Oldridge M, Wilkie AOM, Slaney SF, et al. Mutations in the third immunoglobulin domain of the fibroblast growth factor receptor-2 gene in Crouzon syndrome. Hum Mol Genet 1995;4:1077-82.

19 Judge MR, Michaels M, Sams VR, David TJ, Harper II. Disseminated porokeratosis in an infant with craniosynostosis. Br ₹ Dermatol 1990;123:249-54.

20 Reed RJ, Leone P. A mutant clonal keratosis of the epidermis. Arch Dermatol 1970;101:340-7.

21 Wade TR, Ackerman AB. Cornoid lamellation. $A m f$ Dermatol 1980;2:5-15.

22 Gilchrist TC. Eleven cases of porokeratosis (Mibelli) in on family. F Cutan Genitourin Dis 1899;17:149.

23 Brown FC. Punctate keratoderma. Arch Dermatol 1971;104: 682-3.

24 Shinamato Y, Shinamato H. Differentiation of disseminated superficial actinic porokeratosis from the superficia disseminated eruptive form of porokeratosis of Mibell Cutis 1988;42:345-8

25 Anderson DE, Chernosky ME. Disseminated superficia actinic porokeratosis. Genetic aspects. Arch Dermatol 1969 99:408-12.

26 Solomon LM, Fretzin D, Pruzansky S. Pilosebaceous abnormalities in Apert's syndrome. Arch Dermatol 1970, 102:381-5.

27 Reddy BSN, Garg BR, Padiyar NV, Krishnaran AS. An unusual association of acanthosis nigricans and Crouzon's disease. $\mathcal{F}$ Dermatol 1985;12:85-90.

28 Beare JM, Dodge JA, Nevin NC. Cutis gyratum, acanthosis nigricans, and other congenital anomalies: a new syndrome. Br f Dermatol 1969;81:241-7.

29 Wilkes D, Rutland P, Pulleyn LJ, et al. A recurrent mutation, ala391glu, in the transmembrane region of FGFR3 cause Crouzon syndrome and acanthosis nigricans. $\mathcal{F}$ Med Genet 1996;33:744-8.

30 Orr-Urteger A, Bedford MT, Burakova T, et al. Developmental localization of the splicing alternatives of fibroblast growth

31 Werner S, Smola H, Liao X, et al. The function of KGF in morphogenesis of epithelium and reepithelization of wounds. Science 1994;266:819-22. 